\title{
Front Matter: Volume 11459
}

, "Front Matter: Volume 11459," Proc. SPIE 11459, Saratov Fall Meeting 2019: Computations and Data Analysis: from Nanoscale Tools to Brain Functions, 1145901 (9 April 2020); doi: 10.1117/12.2570907

SPIE Event: Saratov Fall Meeting 2019: VII International Symposium on Optics and Biophotonics, 2019, Saratov, Russian Federation 


\title{
PROGRESS IN BIOMEDICAL OPTICS AND IMAGING

\section{Saratov Fall Meeting 2019 \\ Computations and Data Analysis: from Nanoscale Tools to Brain Functions}

\author{
Dmitry E. Postnov \\ Editor
}

23-27 September 2019

Saratov, Russian Federation

Sponsored by

Saratov State University (Russian Federation)

Research Center of Biotechnology of the Russian Academy of Sciences (Russian Federation)

The Optical Society

LLC SPE Nanostructured Glass Technology (Russian Federation)

INJECT RME LLC (Russian Federation)

AVESTA, Ltd. (Russian Federation)

art photonics $\mathrm{GmbH}$ (Germany)

Becker \& Hickl GmbH (Germany)

Technical Cosponsor and Publisher

SPIE

Volume 11459 
The papers in this volume were part of the technical conference cited on the cover and title page. Papers were selected and subject to review by the editors and conference program committee. Some conference presentations may not be available for publication. Additional papers and presentation recordings may be available online in the SPIE Digital Library at SPIEDigitalLibrary.org.

The papers reflect the work and thoughts of the authors and are published herein as submitted. The publisher is not responsible for the validity of the information or for any outcomes resulting from reliance thereon.

Please use the following format to cite material from these proceedings:

Author(s), "Title of Paper," in Saratov Fall Meeting 2019: Computations and Data Analysis: from Nanoscale Tools to Brain Functions, edited by Dmitry E. Postnov, Proceedings of SPIE Vol. 11459 (SPIE, Bellingham, WA, 2020) Seven-digit Article CID Number.

ISSN: $1605-7422$

ISSN: 2410-9045 (electronic)

ISBN: 9781510637221

ISBN: 9781510637238 (electronic)

Published by

SPIE

P.O. Box 10, Bellingham, Washington 98227-0010 USA

Telephone +1 3606763290 (Pacific Time) · Fax +1 3606471445

SPIE.org

Copyright @ 2020, Society of Photo-Optical Instrumentation Engineers.

Copying of material in this book for internal or personal use, or for the internal or personal use of specific clients, beyond the fair use provisions granted by the U.S. Copyright Law is authorized by SPIE subject to payment of copying fees. The Transactional Reporting Service base fee for this volume is $\$ 21.00$ per article (or portion thereof), which should be paid directly to the Copyright Clearance Center (CCC), 222 Rosewood Drive, Danvers, MA 01923. Payment may also be made electronically through CCC Online at copyright.com. Other copying for republication, resale, advertising or promotion, or any form of systematic or multiple reproduction of any material in this book is prohibited except with permission in writing from the publisher. The CCC fee code is 1605$7422 / 20 / \$ 21.00$.

Printed in the United States of America.

Publication of record for individual papers is online in the SPIE Digital Library.

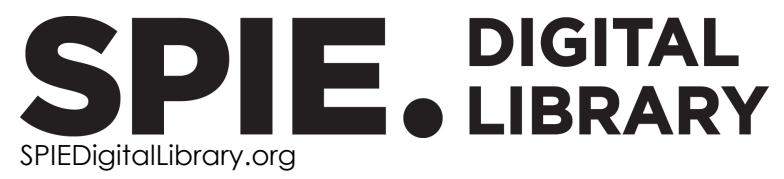

Paper Numbering: Proceedings of SPIE follow an e-First publication model. A unique citation identifier (CID) number is assigned to each article at the time of publication. Utilization of CIDs allows articles to be fully citable as soon as they are published online, and connects the same identifier to all online and print versions of the publication. SPIE uses a seven-digit CID article numbering system structured as follows:

- The first five digits correspond to the SPIE volume number.

- The last two digits indicate publication order within the volume using a Base 36 numbering system employing both numerals and letters. These two-number sets start with $00,01,02,03,04$, 05, 06, 07, 08, 09, OA, OB ... 0Z, followed by 10-1Z, 20-2Z, etc. The CID Number appears on each page of the manuscript. 


\title{
Contents
}

\author{
vii Authors \\ ix Conference Committee \\ xi Introduction \\ xiii Conference Organizers
}

EEG DATA INTERPRETATION

1145902 Recognition of EEG patterns during mental intentions: a comparative study [11459-1]

$1145903 \quad$ Neural activity during maintaining a body balance [1 1459-8]

$1145904 \quad$ Features of motor-related brain activity revealed via recurrence quantification analysis [1 1459-10]

$1145905 \quad$ Using artificial neural networks for classification of kinesthetic and visual imaginary movements by MEG data [1 1459-11]

1145906 Cognitive interaction via a brain-to-brain interface [11459-13]

1145907 Spatio-temporal activity in cortical network during cognitive activity [1 1459-14]

$1145908 \quad$ Network analysis of electrical activity in brain motor cortex during motor execution and motor imagery [1 1459-16]

$1145909 \quad$ Network structure of children's brain activity during cognitive load [11459-18]

11459 OA Maintaining attention state of children during cognitive load [1 1459-19]

11459 OB Analysis of real and imaginary motor activity with combined EEG and fNIRS [1 1459-24]

11459 OC The typical dynamic of various frequency patterns in EEG recordings of post-stroke patients in acute period [1 1459-25]

11459 OD Studying of human's mental state during visual information processing with combined EEG and fNIRS [1 1459-27] 
11459 OE The space-time skeleton method for analyzing EEG data [1 1459-28]

11459 OF The recurrence plot analysis in the processing of experimental biomedical data [11459-20]

11459 OG New methods for processing spatial human electroencephalography based on modified wavelet analysis [11459-21]

$11459 \mathrm{OH} \quad$ Detecting best lag of embedding for modeling spike-wave discharges from experimental data [11459-7]

$11459 \mathrm{Ol} \quad$ The technique for determining on EMG signals the precursors of start of limb movement [1 1459-9]

11459 OJ Detection of early gastric cancer with wavelets [1 1459-4]

11459 OK Identification of the most informative wavelengths for non-invasive melanoma diagnostics in spectral region from 450 to $950 \mathrm{~nm}$ [1 1459-23]

$11459 \mathrm{OL} \quad$ Features of phase synchronization of cardiovascular and respiratory oscillations in humans [11459-6]

11459 OM Synchronization and coherence of the low-frequency components of the signals of the cardiovascular system in newborns [1 1459-26]

\section{MODELING STUDIES ON CARDIOVASCULAR REGULATION AND BRAIN PHYSIOLOGY}

$11459 \mathrm{ON}$ The role of NCX in initiation and expansion of astroglial $\mathrm{Ca}^{2+}$ events in a distributed model [1 1459-30]

1145900 Calcium activity in a sponge astrocyte model with AVF-parameter control [1 1459-31]

11459 OP Functional model of the neurovascular unit: seeking for balance between physiological relevance and computability [11459-32]

$114590 Q \quad$ Opening the BBB could disable neurovascular coupling: the quantitative mathematical model prediction [1 1459-39]

11459 OR Synchronization of cerebral and peripheral blood circulation: stress-induced changes [1 1 459-3]

11459 OS Mathematical modeling of low-frequency oscillations induced by modulated noise in human microvasculature [1 1459-5]

11459 OT Application of cross-recurrent analysis to coupling detection in mathematical model of circulation autonomic control [1 1459-22] 
11459 OU Mathematical model of lymphangion contractility [1 1459-35]

THEORETICAL BIOPHYSICS AND NONLINEAR DYNAMICS

11459 OV Interaction of bistable neurons leading to the complex network dynamics [1 1459-12]

11459 OW Control of dynamics of bistable neural network by an external pulse [11459-15]

11459 OX Inference of functional dependence in coupled chaotic systems using feed-forward neural network [1 1 459-17]

11459 OY Energy exchange of a M-soliton cluster in a 2D Morse lattice [1 1459-33]

$11459 \mathrm{OZ} \quad$ Breathing dynamics of 2-crowdions in platinum [1 1459-34]

1145910 A review of specially discretized Klein-Gordon models [1 1459-37]

$1145911 \quad$ Phase transitions in carbon nanotube bundles under lateral compression [11459-38]

1145912 Scaling features of intermittent dynamics characterized from data sets [11459-2] 
Proc. of SPIE Vol. 11459 1145901-6

Downloaded From: https://www.spiedigitallibrary.org/conference-proceedings-of-spie on 26 Apr 2023
Terms of Use: https://www.spiedigitallibrary.org/terms-of-use 


\section{Authors}

Numbers in the index correspond to the last two digits of the seven-digit citation identifier (CID) article numbering system used in Proceedings of SPIE. The first five digits reflect the volume number. Base 36 numbering is employed for the last two digits and indicates the order of articles within the volume. Numbers start with 00, 01, 02, 03, 04, 05, 06, 07, 08, 09, OA, OB...0Z, followed by 10-12, 20-2Z, etc.

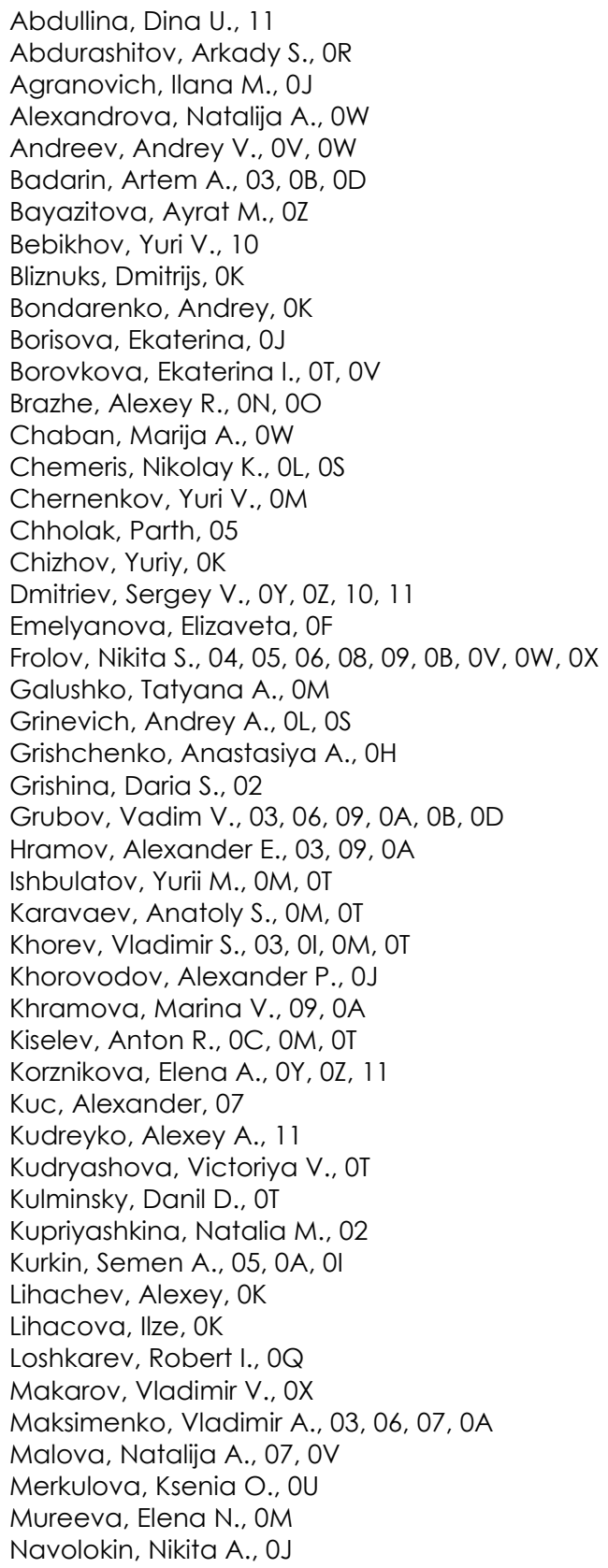

\author{
Navrotskaya, Elena V., ОT \\ Nedaivozov, Vladimir, 06 \\ Niso, Guiomar, 05 \\ Panina, Olga S., OM \\ Pavlov, Alexey N., 02, 0J, OR, 12 \\ Pavlova, Olga N., 02, 0J, OR, 12 \\ Pisarchik, Alexander, 05 \\ Pitsik, Elena N., 04, 08, 09, 0B, 0 \\ Popova, Yulia V., OM, OT \\ Posnenkova, Olga M., OG, OT \\ Postnov, Dmitry E., ON, OO, OP, OQ, OU \\ Pushkarskaja, Darija D., Ol \\ Runnova, Anastasiya E., 02, OC, OE, OF, OG \\ Selskaya, Elena, OF \\ Selskii, Anton, OF \\ Semyachkina-Glushkovskaya, Oxana V., OJ, OR \\ Shepelev, Igor A., OY, OZ, 10, 11 \\ Sitnikova, E., OE \\ Skazkina, Viktoriia V., OD, OM \\ Sysoev, llya $\mathrm{V}$., $\mathrm{OH}$ \\ Sysoeva, Marina $\mathrm{V}_{\text {., }} \mathrm{OH}$ \\ Tankanag, Arina $V_{\text {., }} \mathrm{OL}$, OS \\ Terskov, Andrey $\vee ., O R$ \\ Tikhonova, Irina $\mathrm{V}$. , OL \\ Uteshev, Dilshat, OK \\ van Rijn, Clementina M., $\mathrm{OH}$ \\ Verisokin, Andrey Yu., ON, 00 \\ Verveyko, Darya $\mathrm{V}_{\text {., }} \mathrm{ON}, \mathrm{OO}$ \\ Zakharov, Pavel $\mathrm{V}$., OY, OZ \\ Zhuravlev, Maksim, OC, OE, OF, OG
}


Proc. of SPIE Vol. 11459 1145901-8

Downloaded From: https://www.spiedigitallibrary.org/conference-proceedings-of-spie on 26 Apr 2023 Terms of Use: https://www.spiedigitallibrary.org/terms-of-use 


\section{Conference Committee}

Symposium Chair

Valery V. Tuchin, Saratov State University (Russian Federation), and Tomsk State University (Russian Federation), and Institute of Precision Mechanics and Control, RAS (Russian Federation)

Conference Chairs

Vadim S. Anishchenko, Saratov State University (Russian Federation)

Dmitry E. Postnov, Saratov State University (Russian Federation)

Conference Program Committee

Boris P. Bezruchko, Saratov State University (Russian Federation)

Alexaner B. Neiman, The Ohio University (United States)

Dmitry E. Postnov, Saratov State University (Russian Federation)

Oxana V. Semyachkina-Glushkovskaya, Saratov State University

(Russian Federation)

Anatoly V. Skripal, Saratov State University (Russian Federation)

Olga V. Sosnovtseva, University of Copenhagen (Denmark)

Session Chairs

1 Conference on Computation Biophysics and Analysis of Biomedical Data VI

Dmitry E. Postnov, Saratov State University (Russian Federation)

2 Workshop on Nonlinear Dynamics $X$

Vadim S. Anishchenko, Saratov State University (Russian Federation) Andrei V. Slepnev, Saratov State University (Russian Federation) 
Proc. of SPIE Vol. 11459 1145901-10

Downloaded From: https://www.spiedigitallibrary.org/conference-proceedings-of-spie on 26 Apr 2023 Terms of Use: https://www.spiedigitallibrary.org/terms-of-use 


\section{Introduction}

The Seventh International Symposium on Optics and Biophotonics (Saratov Fall Meeting, SFM19) was held in Saratov, Russian Federation, 23-27 September 2019 with more than 500 participants from the Russian Federation, United States, Canada, Europe and Pacific Ocean countries. It covered a wide range of modern problems of fundamental and applied optics, laser physics, photonics, and biomedical optics, as well as related fields of material science.

The Proceedings of the symposium are published in three SPIE volumes. The present volume includes selected papers of the following conferences and workshops organized in the framework of the symposium:

\section{Computation Biophysics and Analysis of Biomedical Data VI Dmitry E. Postnov (Chair) \\ Nonlinear Dynamics $\mathrm{X}$ \\ Vadim S. Anishchenko (Chair)}

This volume begins with a section devoted to the analysis of electroencephalogram data. The results of the study of EEG changes in solving various mental and cognitive tasks, while maintaining the balance of the body, while comparing the actual and imaginary activity, while processing visual information are presented. The works collected in this part of the volume carry a general main message: the analysis of EEG data allows us to solve more and more subtle tasks of detecting brain states, such as a really performed action or just the intention to do it. Of particular interest are works where changes in the EEG are compared with data obtained by other methods, such as fMRI.

The next section of the volume contains works that also operate on electrophysiological and optical data but are more focused on improving the method of extracting information. Here we can see a tendency towards more intelligent and complex post-processing of data using spatial-temporal analysis methods, such as wavelet-analysis.

The next section is devoted to model studies of physiological processes, both in the neurovascular unit of the brain, where, in particular, the activity of astrocytes is modeled, and at the systemic level, as applied to the cardiovascular system as a whole.

Finally, the last but not the least section on theoretical biophysics and nonlinear dynamics covers a range of studies of the basic dynamics patterns that underlie many biophysical processes, including complex network dynamics at levels from neural to atomic (crowdions). 
This is the third volume of Saratov Fall Meeting 2019. The preface to the first volume Optical and Nano-Technologies for Biology and Medicine, edited by Elina A. Genina and Valery V. Tuchin, provides the reader with thorough and impressive information about the entire event of Saratov Fall Meeting 2019.

On behalf of SFM19 organizers, the editor of this volume thanks all authors for their contributions to the symposium. We are also grateful to all the sponsoring organizations and programs that efficiently supported the meeting: Saratov State University (Russian Federation); Research Center of Biotechnology RAS (Russian Federation); SPIE - The International Society of Photo-Optical Instrumentation Engineers; The Optical Society; Art Photonics GmbH (Germany); Avesta Projects Ltd. (Russian Federation); Becker \& Hickl GmbH (Germany); RME INJECT, LLC (Russian Federation); LLC SPE Nanostructured Glass Technology (Russian Federation).

Dmitry E. Postnov 


\title{
Conference Organizers
}

\author{
Saratov State University (Russian Federation) \\ Research-Educational Institute of Optics and Biophotonics of Saratov State \\ University (Russian Federation) \\ International Research-Educational Center of Optical Technologies for Industry \\ and Medicine "Photonics" of Saratov State University (Russian Federation) \\ Institute of Biochemistry \& Physiology of Plants \& Microorganisms of the RAS \\ (Russian Federation) \\ Institute of Precision Mechanics and Control of the RAS (Russian Federation) \\ Saratov State Medical University named after V.I. Razumovsky \\ (Russian Federation) \\ Volga Region Center of New Information Technologies of Saratov State University \\ (Russian Federation) \\ Tomsk State University (Russian Federation) \\ ITMO University (Russian Federation) \\ Bauman Moscow State Technical University (Russian Federation) \\ Institute of Solid-State Physics of the RAS (Russian Federation) \\ Prokhorov Institute of General Physics of the RAS (Russian Federation) \\ Research Center of Biotechnology of the RAS (Russian Federation) \\ Biomedical Photonics Committee of Chinese Optical Society (China) \\ SPIE Student Chapters of: \\ Saratov State University (Russian Federation), \\ Bauman Moscow State Technical University (Russian Federation), \\ Institute of Solid-State Physics of the RAS (Russian Federation), and \\ Samara University (Russian Federation) \\ OSA Student Chapters of: \\ Saratov State University (Russian Federation) and \\ Bauman Moscow State Technical University (Russian Federation)
}


Proc. of SPIE Vol. 11459 1145901-14

Downloaded From: https://www.spiedigitallibrary.org/conference-proceedings-of-spie on 26 Apr 2023 Terms of Use: https://www.spiedigitallibrary.org/terms-of-use 